Medieval Robots 
THE MIDDLE AGES SERIES

Ruth Mazo Karras, Series Editor

Edward Peters, Founding Editor

A complete list of books in the series

is available from the publisher. 


\title{
Medieval Robots
}

\section{$\cos$}

Mechanism, Magic, Nature, and Art

\section{E. R. Truitt}

\author{
PENN \\ UNIVERSITY OF PENNSYLVANIA PRESS \\ PHILADELPHIA
}




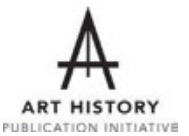

This book is made possible by a collaborative grant from the Andrew W. Mellon Foundation.

Copyright (C) 2015 University of Pennsylvania Press

All rights reserved. Except for brief quotations used for purposes of review or scholarly citation, none of this book may be reproduced in any form by any means without written permission from the publisher.

\author{
Published by \\ University of Pennsylvania Press \\ Philadelphia, Pennsylvania I9IO4-4II2 \\ www.upenn.edu/pennpress
}

Printed in the United States of America on acid-free paper

I 3579 IO 8642

Library of Congress Cataloging-in-Publication Data

ISBN 978-0-8I22-4697-I 
To Katharine Park, doctor mirabilis 
This page intentionally left blank 